\title{
The Impact of Reputation on Corporate Financial Performance: Median Regression Approach
}

\author{
Silvija Vig \\ Polytechnic of Međimurje, Čakovec, Croatia \\ Ksenija Dumičić \\ Faculty of Economics \& Business, Zagreb, Croatia \\ Igor Klopotan \\ University North, Varaždin, Croatia
}

\section{Abstract}

Background: In recent years, reputation has become an important risk concern for companies around the world. Deloitte Global Survey highlights the reputation risk as the top strategic business risk in 2014. This is also proven by a research conducted by AON Global Risk Management Survey in 2015 and Allianz Risk Barometer Survey in 2016 which finds a loss of reputation as one of the biggest risks for business executives. Furthermore, the importance of reputation is confirmed by the fact that reputation accounts for more than 25 percent of a company's market value and the total market capitalization of the S\&P500 companies. Objectives: To investigates the relationship between corporate reputation and financial performance. Methods/Approach: The survey of the paper was conducted in 2015 in Croatia. The questionnaire for assessing corporate reputation contained three reputational dimensions: products and services, corporate integrity, and organizational performance while the financial dimensions contained indicators of EVA, ROCE, ROA, ROE and the financial stability coefficient. Hierarchical regression methods were applied in the analysis. Results: This research leads to the conclusion that some dimensions of corporate reputation can be important predictors of financial performance. Conclusions: Results of the research could be a valid motivation for business executives to consider reputation risk as a critical issue of corporate business strategy.

Keywords: business ethics; corporate reputation; financial performance; hierarchical regression; reputation risk

JEL classification: $M$

Paper type: Research article

Received: May 14, 2017

Accepted: Jul 28, 2017

Citation: Vig, S., Dumičić, K., Klopotan, I. (2017), "The Impact of Reputation on Corporate Financial Performance: Median Regression Approach", Business Systems Research, Vol. 8, No. 2, pp. 40-58.

DOI: 10.1515/bsrj-2017-0015

Acknowledgment: This work has been partially supported by the Croatian Science Foundation within the project STRENGTHS (project no. 9402). 


\section{Introduction}

In today's fast-changing world and in the uncertain and complex business environment, companies that are oriented on exclusively short-term financial business results are exposed to increasingly larger business risks which they have to manage often and with new ways of doing so. Hence, numerous companies besides financial indicators also include non-financial ones in their strategic goals which predict sustainable long-term business. One of the most significant ones but also a very sensitive non-financial construct is the corporate reputation that already today represents one of the key intangible assets for creating an added value of a company. On one hand, reputation represents value, but on the other, it creates a company's value. However, because of its sensitive nature, although it takes years to create it, it can be destroyed in a heartbeat. It is for this reason that business executives of numerous companies list it as one of the biggest business risks, and this is confirmed by numerous research papers.

The Deloitte Global survey stated reputation risk as the top strategic business risk in 2013, and in the survey conducted in 2014 they emphasize the importance of managing reputation risk as a problem of strategic business issues which in current conditions becomes an imperative in business (Deloitte, 2014). Furthermore, the Allianz Risk Barometer $(2015,2016)$ states that the loss of reputation is one of the ten most significant business risks and the "main cause of a company's economic loss after a cyber incident, stopping of business or damage that was caused because of loss of client data". Also, AON Global Risk Management Survey 2017 considers the destruction of reputation as the greatest risk of business in 2017. Also, the abovementioned research emphasizes the importance of the influences of new technologies on the speed of news proliferation that can destroy a reputation in a very short time, especially of global companies because bad news in one part of the world today via the Internet and social networks is available only moments after in all other parts of the world. The fact the other risks like ethics risk and harmonization amidst possible frauds, corruptive activities or discriminations; security risk including cyber risk, protection of personal data; product risk and services and third party risk which companies do not directly influence, also point to the sensitivity of reputation risk.

Reputation represents an intangible asset that is very difficult to copy, that has been created on the basis of former events and activities of companies and something that creates a company's perception in public (Fombrun and van Riel, 1997). Numerous researches confirm its positive effects on financial and non-financial success of the business of a company (De la Fuente Sabaté and De Quevedo Puente, 2003; Turban and Cable, 2003; Sobol and Farrelly, 1988). The analysis of the current literature has shown that most research (Orlitzky, 2005; De la Fuente Sabaté and De Quevedo Puente, 2003; Brown, 1998; Griffin and Mahon, 1997) measures the influence of the total company reputation which consists of various dimensions on certain aspects of the business including financial performance indicators.

The aim of this research is to measure the impact of individual dimensions of reputation on financial business performance. Also, it has been noted that current research on the influence of reputation on financial indicators is mostly based on traditional financial indicators. In contemporary business conditions, traditional financial indicators as instruments of measuring and evaluating business performance are exposed to critiques that are connected to "insufficient risk acknowledgement, insufficient time value of money acknowledgement, influence of the balance politics and that are insufficiently connected to the shifts on the capital market, or that the traditional indicators do not sufficiently reflect growth of value in 
the market" (Sever Mališ, 2017, p. 424). So, this research besides traditional financial indicators also includes a contemporary measure of a company's business performance. Except that, there is another fact which, from our point of view, needs to be explained and it refers to the definition of the term and the variables that make up corporate reputation for which there is still no unified attitude. Therefore, the goal of this paper is to explain reputation as a construct of three interconnected variables. Besides that, this work analyses the correlation between individual dimensions of corporate reputation and financial performance in Croatian companies. The paper will significantly contribute to the understanding of corporate reputation and its importance in the business activity of a company. The results of the research can be used in practice, executive directors as guidelines for making business decisions and in the scientific community to the researchers as a basis for some future comparable research in Croatia, in the region as well as outside of it.

\section{Literature review}

\section{Corporate reputation}

In numerous dictionaries there is a clear definition of the term reputation, so the Oxford dictionary states that reputation is "the beliefs or opinions that are generally held about someone or something" (Oxford dictionary online, 2017), Cambridge dictionary considers reputation "the opinion that people in general have about someone or something, or how much respect or admiration someone or something receives, based on past behavior or character" (Cambridge dictionary, 2017), Merriam-Webster dictionary defines reputation as an "overall quality or character as seen or judged by people in general" (Merriam-Webster dictionary, 2017). However, its meaning in the business world is still not unified. Different authors state numerous definitions of corporate reputation that differ in interpretation but also its characteristics. Wartick states that the term like identity, as well as image and corporate reputation are often used interchangeably (Barnett et al., 2006). So, we think it is important that before we define the term of corporate reputation to explain the terms like identity and image that in literature and practice are often used as synonyms or interrelated phenomena so we could make their meaning and interrelationship clearer. In this paper terms like identity, image and corporate reputation are seen as different but also as interrelated phenomena.

Corporate identity represents the basic character of a company which determines what the company really is. In other words, the identity reflects the philosophy of the business activity of a company, its values, behaviors and activities towards all of its stakeholders. Corporate identity is formed by a "merging of strategy, structure, communication and culture and it is manifested through multifarious communications channels encapsulating product and organizational performance, employee communication and behavior, controlled communication and stakeholder and network discourse" (Bendixen and Abratt, 2007:70-71). The organizational structure plays a large role in the forming of the corporate identity which through its formal and informal systems implements the founding values in a company's business activity. Since the organizational culture defines values and standards of behavior in the company, it affects the behavior of management and employees. If a company strives for a good reputation and long-term sustainable performance, it is important that the organizational culture is based on ethical values which then make up the ethical identity of a company. 
Whereas corporate identity says who we are as a company, or rather shows what the company claims it is, corporate image represents how others perceive a company. "Corporate image is the mental picture of the company held by its audiences-what comes to mind when one sees or hears the corporate name or sees its logo" (Gray and Balmer, 1998). Since the image depends on the observer perception it is often seen as the same thing as reputation. Gotsi and Wilson (2001) in their research reveal that there are two different views connected to image and reputation. The first view states that image and reputation are almost identical, or rather that both terms can be used as synonyms. Numerous authors agree with the premise of the synonymity of the terms of image and reputation (see Gotsi and Wilson, 2001). Secondly, image and reputation are not the same terms but are interrelated in a way that: a) reputation affects or b) that image affects reputation (Gotsi and Wilson, 2001). Although there are authors in the literature that support the view that reputation affects image (Barich and Kotler, 1991; Mason, 1993), there are still slightly more of them that lean towards the presupposition that image affects reputation (see Gotsi and Wilson, 2001). According to Fombrun and van Riel (1997) identity and image represent the basic elements of reputation.

This construct can be shown through the views of self-psychology that was developed by Heinz Kohut. The self represents a "mental system that organizes a person's subjective experience in relation to a set of developmental needs" (Wolf, 1988 cited in Banai et al., 2005), and since a company is an economic, technological, legal and sociological system that represents the community of persons, Kohut's views could be applied in the context of reputation management. "The Self is an experience of itself" (Gruden, 2003), or rather what we are, which in the context of a company would represent corporate identity. The subjective experience of the self as an object forms self-representation which in the context of a company would be image. The problem occurs because self-representation, as well as image can be real or if there is no congruence between the self and the selfrepresentation, the self-representation becomes false. In line with that, in a business context if the identity and image of a company are congruent it creates a positive reputation and if they are not, or there is too much distance between identity and image, the reputation is as bad in the long-term as the false self is false.

It is important to point out that a company can affect and control its identity, which represents a very stable variable, but even though it creates its image, the company has no control over its image or its reputation because of external factors that affect them. The media or some sudden events can be triggers in the perception of a good or bad reputation for eternal stakeholders. Since the reputation consists of "the knowledge and emotions held by individuals" (Hall, 1992, p. 138), or rather "the combination of affective and cognitive components" that determine the "reputation as an attitudinal construct, where attitude denotes subjective, emotional, and cognitive based mindsets" (Schwaiger, 2004, p. 49), it represents a delicate and "a fragile resource; it takes time to create, it cannot be bought, and it can be damaged easily" (Hall, 1993, p. 616).

\section{Business ethics as a premise for good corporate reputation}

Corporate reputation is the reflection of a company's past procedures and activities in the eyes of the stakeholders which based on their affective and cognitive perceptions evaluate them as being good or bad. Ethics as a science on morality gives answers to the questions of what is good, bad, right or wrong while business ethics gives these answers in a business context. It encompasses the values, principles and standards that direct behavior and activities in the business world and 
is seen as the basis of all business relationships. Even though in the nineties, when it was started to be implemented into business systems, it was considered a fad (Treviño and Nelson, 2011), today it is unthinkable to realize long-term sustainable performance without its implementation. Furthermore, Fombrun and Foss (2004) prove that business ethics affect the reputation, image and competitiveness of a company.

As the impression that company's leave in the public eye has gotten ever more important and the demands of the stakeholders have risen, many companies have realized that they have to implement ethical business standards, most often defined by programs of business ethics, which consist of: (1) values and mission, (2) codes of ethics, (3) ethics officers, (4) ethics helpline, (5) ethics training programs, (6) communicating ethical values, (7) rewarding policy for ethical behavior, and (8) ethics audit (Vig and Dumičić, 2016). The value and mission on which a company bases its business activity make up an ideological core, or rather, identity, the so called, character of a company (Collins and Porras, 2002). They determine how a company presents itself, how it works and what kind of impression it makes on the public. To be able to leave a positive impression, companies need to base their business activity on ethical values that are embedded in the mission and vision of the company so it can continuously remind the employees that their current and future behavior and activities are right.

\section{Reputation measuring}

Reputation, as was mentioned earlier, represents a valuable and intangible asset. To prove its value, reputation needs to be measured. However, because of its intangible characteristic and affective-cognitive component of the observer, it is hard to measure. So, till this day there is still no standardized instrument only individual authors and institutions that create rating lists with different numbers of variables.

Although looking into reputation started in the fifties of the last century, it was only at the start of the eighties that reputation was first measured (Grgić, 2008a). The most known measurement till today was performed by Fortune magazine during the fall of 1983 (Ponzi et al., 2011), and in 1984 the list of "America's Most Admired Companies" (Fombrun et al., 2000) was published for the first time. Reputation was rated by managers and business analysts in their respective branches of industry based on eight criteria from investment value, product quality and services to social responsibility (Ponzi et al., 2011). Since 1997 the list has grown into the "Global Most Admired Companies" (Fombrun et al., 2000), today known as the "World Most Admired Companies" and it is based on nine criteria that are measured in 51 different branches of industry: "innovation, quality of products and services, quality of management, people management, use of corporate assets, long-term investment value, financial soundness, global competitiveness and social responsibility" (Fortune, 2017). In time also other magazines and institutions in the world started to rate the companies that had the best reputation, according to their own criteria, like "Management Today (Britain's Most Admired Companies), Financial Times (World's or Europe's Most Respected Companies), Corporate Branding LLC (Corporate Branding Index), Asian Business (Asia's Most Admired Companies) and others" (Schwaiger, 2004, p. 56). Year after year, the number of lists grew so that already in 2007 the Reputation Institute identified 183 public lists that rate companies according to their reputation in 38 countries (Fombrun, 2007), so that number is today surely even greater.

Since the above-mentioned lists are mainly based on the perception and views of the managers and analysts, Charles Fombrun in together with the market research 
company Harris Interactive 1999 developed a new instrument of measurement the Reputation Quotient (RQ) to be the standard in reputation measuring of companies, in order to see what the perception of different stakeholders is. Fombrun et al. (2000, p. 242) state that corporate reputation is a "collective construct that describes the aggregate perceptions of multiple stakeholders about a company's performance. Since corporate performance is a multi-dimensional construct, reputation would be expected to be multi-dimensional as well, reflecting the unique dimensions on which individuals stakeholders base their judgments of the company's performance." Reputation Quotient consists of 20 items divided into six criteria (Fombrun et al., 2000, p. 252): "(1) Emotional Appeal, (2) Products and Services, (3) Financial Performance, (4) Vision \& Leadership, (5) Workplace Environment, and (6) Social Responsibility".

By noticing the importance of a company's relationship to its stakeholders, Grgic (2012) added relationships, as one of the fundamental dimensions that affect the creation of a company's positive reputation, in the Reputation Quotient and creates the Index of company reputation (IRP). As opposed to measurements till then that measured relationships separately, this instrument of measurement includes relationships as one of the dimensions of reputation (Grgić, 2012).

According to Ponzi et al. (2011) numerous other authors developed their own instruments of measurement with different numbers of criteria, like a 28-item customer-based reputation measure (Walsh and Beatty, 2007), 15-items scale, a tenitem scale (Helm, 2005), a six-item corporate reputation measure (Schwaiger, 2004), a four-item scale (Hammond and Slocum, 1996) or a three-item scale (Highhouse et al., 2003).

Since in their paper, Highhouse et al. (2009) suggest that "stable estimates of global reputation can be achieved with a small number of items", Klopotan (2016) reduces the instrument of reputation measurement to three dimensions which consist of a total of nine questions: (1) Company reputation: Products and services (Guarantee for products and services, development of innovative services, quality of products and services, level of products and services for the given price - value for money); (2) Company reputation: Vision (Company management, vision for the future, quality of leadership); and (3) Company reputation: Working condition (Company quality as a job provider, Quality of the employees) which are the subject of research in this paper.

\section{Impact of reputation on corporate financial performance}

By analyzing the current literature the conclusion is that there are two types of research for corporate reputation and financial performance indicators. The first group, which is also less rare, is research on the effect of financial performance indicators on corporate reputation (Hamond and Slocum, 1996; Sobol and Farrelly, 1988). The second, also the bigger group is opposite research, or rather that that measures the effect of reputation on the financial performance of a company. When looking into this second group of research the conclusion is that there are more positive relationships compared to the research with no relationships or even negative relationships between reputation and financial indicators or even negative relationships. Added difficulties in the implementation of the results are created because of the use of different instruments of measurement of a company's reputation by individual authors and the use of different accounting-based or market-based measures.

Ugoji et al. (2007) by analyzing key scientific research by Orlitzky et al. (2003), Roman et al. (1999) and Griffin and Mahon (1997) summed up the research that measured the relationships of financial indicators and indicators of business 
ethics/social responsibility. The results show that of a total of 80 research papers, 38 display positive relationships, 18 display no significant relationships, 7 display negative relationships and display 17 mixed relationship (Ugoji et al., 2007). Out of the 80 above-mentioned research papers, 16 of them for measuring reputation use the Fortune magazine instrument of measurement, and are for the purposes of this paper shown in table 1 so the relationship of reputation, measured with the same instrument of measurement and financial performance indicators, which in the abovementioned research differs from one author to the next.

Table 1

An overview of research papers that include an instrument of measurement of reputation by the Fortune magazine and financial indicators

\begin{tabular}{|c|c|c|}
\hline Studies & Measures of Social Performance & $\begin{array}{l}\text { Measures of financial } \\
\text { performance }\end{array}$ \\
\hline \multicolumn{3}{|l|}{ Positive relationship } \\
\hline Brown (1998) & Fortune Reputation Ratings & Market measures \\
\hline Brown and Perry (1995) & $\begin{array}{l}\text { Fortune's ratings of "responsibility to } \\
\text { the community" (Reputational } \\
\text { indices) }\end{array}$ & $\begin{array}{l}\text { Composite of Return on } \\
\text { Asset, Market/Book Value, } \\
\text { log of sales and risk }\end{array}$ \\
\hline $\begin{array}{l}\text { Connie and Madden } \\
\text { (1986) }\end{array}$ & Fortune Reputation Ratings & $\begin{array}{l}\text { Perception of the reliability } \\
\text { of financial position and of } \\
\text { value as long run } \\
\text { investment }\end{array}$ \\
\hline Cottrill (1990) & Fortune Reputation Ratings & Market share \\
\hline Griffin and Mahon (1997) & $\begin{array}{l}\text { Fortune Reputation Survey, index } \\
\text { score, KLD, Corporate Philanthropy, } \\
\text { Toxics Release Inventory (TRI), }\end{array}$ & $\begin{array}{l}\text { ROS, ROE. ROA. SIZE (log of } \\
\text { total assets) and Asset age }\end{array}$ \\
\hline $\begin{array}{l}\text { Herrmans' Akathaporn } \\
\text { and Mclnnes (1993) }\end{array}$ & Fortune Reputation Ratings & Abnormal Market Returns \\
\hline $\begin{array}{l}\text { McGuire, Sundgren and } \\
\text { Schneeweis (1988) }\end{array}$ & Fortune Reputation Ratings & $\begin{array}{l}\text { ROA, alpha, asset growth, } \\
\text { operating income growth } \\
\text { and sales growth }\end{array}$ \\
\hline $\begin{array}{l}\text { Preston and Sapienza } \\
(1990)\end{array}$ & Fortune Reputation Ratings & Market measures \\
\hline Riahi - Belkaoui (1991) & Fortune Reputation Ratings & $\begin{array}{l}10 \text { years' EPS growth and } \\
\text { P/E Ratio }\end{array}$ \\
\hline Simerly (1994) & $\begin{array}{l}\text { Fortune Reputation Scores, } \\
\text { dichotomized }\end{array}$ & $\begin{array}{l}\text { Share price, EPS, ROE, } \\
\text { market value, sales rate, } \\
\text { sales/equity and ROI }\end{array}$ \\
\hline $\begin{array}{l}\text { Spencer and Taylor } \\
\text { (1987) }\end{array}$ & Fortune Reputation Ratings & ROA and ROS \\
\hline $\begin{array}{l}\text { Tichy, Mc Gill and St. } \\
\text { Clair (1997) }\end{array}$ & Fortune Reputation Ratings & Accounting measures \\
\hline $\begin{array}{l}\text { Wokutch and Spencer } \\
\text { (1987) }\end{array}$ & $\begin{array}{l}\text { Fortune Reputation Ratings, } \\
\text { charitable contributions and } \\
\text { corporate crime }\end{array}$ & ROA and ROS \\
\hline \multicolumn{3}{|l|}{ Mixed relationship } \\
\hline Brown (1997) & Fortune Reputation Ratings & Market measures \\
\hline $\begin{array}{l}\text { McGuire, Schneeweis } \\
\text { and Branch (1990) }\end{array}$ & Fortune Reputation Ratings & $\begin{array}{l}\text { Accounting and Market } \\
\text { measures }\end{array}$ \\
\hline
\end{tabular}

Source: Ugoji, et al. (2007)

From the above-mentioned table the conclusion is that reputation is in a positive relationship with numerous accounting-based and market-based measures. This is 
supported with the claim that "the greatest reasons for a positive effect on a social performance of a company on its financial results is because of reputation" (Orlitzky, 2005). De la Fuente Sabaté and De Quevedo Puente (2003) in their study mentioned similar theses, or rather that reputation has a positive effect on financial indicators but they also mention research in which no effect has been noticed (Schultz et al., 2000 cited in De la Fuente Sabaté and De Quevedo Puente, 2003). Roberts and Dowling (2002) think that a great corporate reputation helps companies to achieve exceptional financial performance. However, Fombrun and Shanley (1990) agree with authors that support the opposite relationship of variables and think that "it may be more fruitful to consider financial performance as a variable influencing... (reputation) than the reverse" (Fombrun and Abrahamson, 1988 cited in Fombrun and Shanley, 1990, p. 237). On these grounds, we argue that a great reputation represents an important resource that has a positive effect on financial performance of a company. Based on that, we pose the following hypotheses:

H1: There is a significant impact of products and services as a dimension of corporate reputation on financial performance.

The hypothesis stems from the fact that the buyers are very important stakeholders, so managing their expectations and perceptions is the key of the success of any company (Delloitte, 2014). So, the products and services quality as one of the basic dimensions of reputation management (Grgić, 2012) is an important predictor of financial performance.

The leadership of a company plays a large role in creating and implementing the organizational culture that affects the identity, image and in the end the corporate reputation. Often corporate reputation is evaluated precisely by the behavior and performance of the leaders of that company (Grgić, 2012). So, their performance based on the adopted values as well as on the vision of a company, significantly affects the overall reputation which in the end can affect the financial performance of a company. In line with that, we pose the second hypothesis in this paper:

H2: There is a significant impact of vision and leadership as a dimension of corporate reputation on financial performance.

The working environment climate affects decision making and behaviors and performance of the employees. Companies with a good reputation mostly have an ethical organizational climate which determines the atmosphere inside the company and causes employees to behave and perform ethically (Treviño et al., 1998). Such a working environment has a positive effect on moral, dedication and productivity of the employees (ISO, 2014) and their satisfaction with the working environment and the company in which they work (Peterson, 2004 cited in Grgić, 2008b). Companies with a good reputation represent quality job providers for which employees want to work. Based on that:

H3: There is a significant correlation between working conditions as a dimension of corporate reputation and financial performance.

\section{Methodology}

\section{Sample}

The analysis of a company's reputation is based on measuring three dimensions of reputation: product and service, vision and leadership and working environment. The primary empirical research was carried out on the Croatian population, where the reported unit was citizens from ages 18 to 65 who were asked to evaluate the reputation of 100 selected companies. The examinees were contacted by e-mail and they received a digital questionnaire. Companies that the examinees were 
asked to evaluate were randomly selected out of a list of 400 biggest companies that is published by the Privredni vjesnik, based on the data of the Croatian Chamber of Economy (HGK). The research was done in 2015 and a total of 400 filled out questionnaires were collected. The research instrument used in this research is one developed by Klopotan (2016) based on the Index of company reputation (Grgić, 2012), and consists of three dimensions of reputation: product and service reputation, vision and leadership reputation and working conditions reputation, as is shown in table 2. The questions are posed in a way that the examinees should express their agreement with a certain assertion on the Likert scale (7-point).

Table 2

Research instrument of company reputation (Likert scale 1-7)

\begin{tabular}{ll}
\hline Variable code & \\
\hline P1 & Company reputation: Products and services \\
P2 & Guarantee of products and services \\
P3 & Development of innovative services \\
P4 & Quality of products and services \\
& $\begin{array}{l}\text { Level of products and services for a given price (Value for } \\
\text { V1 }\end{array}$ \\
V2 & Company reputation: Vision and leadership \\
V3 & Vision for the future \\
W1 & Quality of leadership \\
W2 & Quality of a company as an employer \\
\hline Source: Klopotan (2016) according to Grgić (2012)
\end{tabular}

The financial indicators of performance of the selected companies have been gathered from the database of the Financial Agency (FINA), the leading company for business information in Croatia, for 2016, and include the traditional indicators of performance: ROA, ROE, ROCE and the current measure of performance, also the most significant, Economic value added (EVA), as is shown in table 3.

Table 3

Company performance measurement

\section{coefficient}

ROCE

ROA

ROE

EVA

Source: Author's work

\section{Statistics}

The characteristics of the examinees, like gender, age, level of education and current status, were gathered in the scope of the research. According to the data shown in table $4,45.40 \%$ were female and $52.50 \%$ were male. The largest number of examinees were until the age of $25(22.50 \%)$, then from 26 to $30(22 \%)$, and from 31 to 35 (16\%). The least number of examinees were in the age group that is older than 61 
(4.25\%). The most examinees were high school graduates $(36.40 \%)$ or college graduates (35.44\%) and most of the examinees were employed (38.50\%).

Table 4

Participant characteristics

\begin{tabular}{|c|c|c|c|}
\hline & Number of examinees & Structure in \% & Cumulative \% \\
\hline \multicolumn{4}{|c|}{ Gender } \\
\hline No answer & 8 & 2,00 & 2.00 \\
\hline Male & 182 & 45.50 & 47.50 \\
\hline \multirow[t]{2}{*}{ Female } & 210 & 52.50 & 100.00 \\
\hline & & & Age \\
\hline No answer & 2 & 0.50 & 0.50 \\
\hline Until 25 & 90 & 22.50 & 23.00 \\
\hline $26-30$ & 88 & 22.00 & 45.00 \\
\hline $31-35$ & 64 & 16.00 & 61.00 \\
\hline $36-40$ & 52 & 13.00 & 74.00 \\
\hline 41-45 & 43 & 10.75 & 84.75 \\
\hline $46-50$ & 26 & 6.50 & 91.25 \\
\hline $51-60$ & 18 & 4.50 & 95.75 \\
\hline \multirow[t]{2}{*}{ More than 61} & 17 & 4.25 & 100.00 \\
\hline & & & Education \\
\hline No answer & 5 & 0.25 & 0.25 \\
\hline High school graduate & 144 & 36.4 & 36.65 \\
\hline Vocational school & 94 & 23.63 & 60.29 \\
\hline College graduate & 140 & 35.44 & 95.73 \\
\hline \multirow[t]{2}{*}{ Masters or doctorate } & 17 & 4.27 & 100 \\
\hline & & & Status \\
\hline Student & 104 & 26.00 & 26.00 \\
\hline Unemployed & 98 & 24.50 & 50.50 \\
\hline Employed & 154 & 38.50 & 89.00 \\
\hline Company owner / manager & 28 & 7.00 & 96.00 \\
\hline Retired & 16 & 4.00 & 100.00 \\
\hline
\end{tabular}

Source: Klopotan (2016)

Since a standard linear regression gives only a partial view of an average relationship between independent and dependent variables (Baum, 2013), we used a median regression in this research. The median is a 50 percentile or a 0.5 quantile of the empirical distribution or rather "the quantile $q \in(0.1)$ is that $y$ which splits the data into proportions $q$ below and $1-q$ above: $F(y q)=q$ and $y q=F-1(q)$ : for the median, $q=0.5 "$ (Baum, 2013, p. 2).

The linear median regression model is used when there is an assumption that "the conditional median of the dependent variable $y$ is a linear function of the vector $x$ of independent variables" and is "particularly suitable if the conditional distribution of the $y$ variable is fat-tailed, or if the lowest and/or highest values of $y$ are truncated or misreported" (Bierens and Ginther, 2000).

Table 5 shows the calculation of the middle value and the median for dependent variables of financial performance indicators of a company. 
Table 5

Company performance from the sample

\begin{tabular}{|c|c|c|c|c|c|c|}
\hline & & Minimum & Maximum & Mean & $\begin{array}{l}\text { Std. } \\
\text { Deviation }\end{array}$ & Median \\
\hline ROCE & 100 & -1.088 & 5.643 & 0.111 & 0.636 & 0.033 \\
\hline ROA & 100 & -82.383 & 29.902 & 2.646 & 13.567 & 3.801 \\
\hline ROE & 100 & -396.938 & 188.255 & 3.317 & 54.277 & 4.452 \\
\hline EVA & 100 & $-1.8 E+09$ & 3.71E+08 & $-8.1 E+07$ & $2.79 E+08$ & $-2.0 E+07$ \\
\hline
\end{tabular}

Source: Author's work

For the dependent variable ROCE, the median of 0.033 indicates where the center of the data is located. Thus, the typical ROCE is 0.111 (mean value). The median for ROA is 3.801 and the mean is 2.646 , which determine the typical ROA. The median for ROE is 4.452 and the mean is 3.317 , which determine the typical ROE and the median for EVA is $-2.0 E+07$ where the center of the data is located and the mean of $-8.1 \mathrm{E}+07$ determine the typical EVA. The histograms of this data are shown below.

Figure 1

Comparison between ROCE, ROA, ROE and EVA median
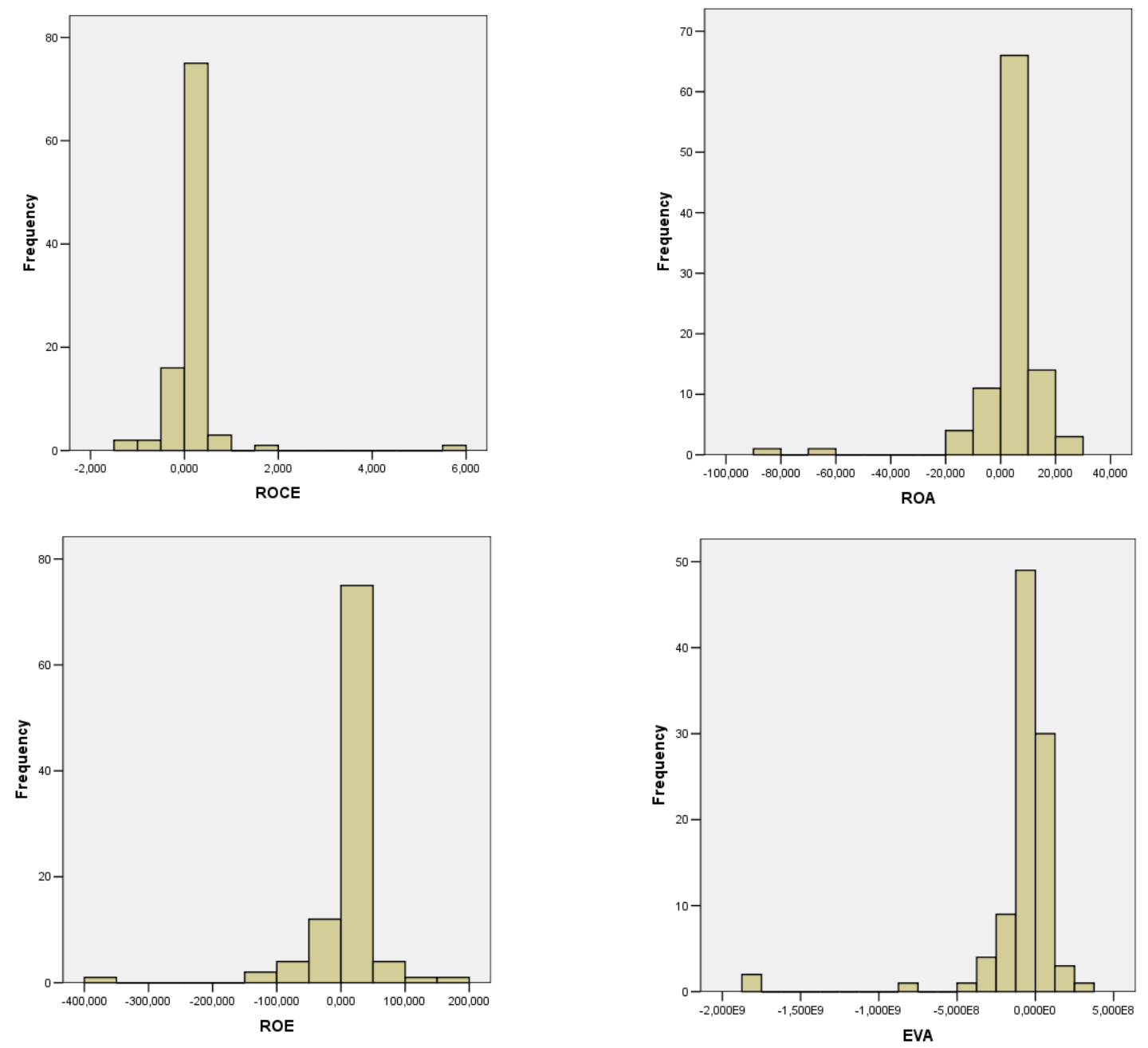

Source: Author's work 
Since the mean is slightly lower than the median, as is the case with the ROA, ROE and EVA, the histogram is slightly skewed in a negative direction and vice versa, and in our research this is the case with the ROCE.

\section{Findings}

The research goal is to investigate the influence of each individual dimensions of corporate reputation, as the dependent variable on the financial performance of Croatian companies, as presented in table 6 . The median regression with a dependent binomial variable was used, which takes on the values: (a) 0 for $50 \%$ of companies that have values of variables ROCE, ROA, ROE and EVA less than the median and (b) 1 for $50 \%$ of companies that have values of variables ROCE, ROA, ROE and EVA greater or equal to the median.

Table 6

Estimation of statistical parameters of the median regression model

\begin{tabular}{rrrrr}
\hline & ROCE & ROE & ROA & EVA \\
\hline const & $\tau=0.5$ & $\tau=0.5$ & $\tau=0.5$ & $\tau=0.5$ \\
P1 & -0.066 & -5.474 & -4.949 & $-5.579 \mathrm{e}+06$ \\
\hline P2 & 0.036 & 0.941 & -2.202 & $-7.656 \mathrm{e}+06$ \\
\hline P3 & 0.001 & 1.729 & 0.939 & $1.819 \mathrm{e}+07^{* *}$ \\
\hline P4 & -0.024 & $-4.358^{*}$ & 0.540 & $-1.604 \mathrm{e}+07$ \\
V1 & -0.018 & 0.436 & 0.339 & $3.397 \mathrm{e}+06$ \\
\hline V2 & 0.034 & 1.003 & 0.741 & $1.256 \mathrm{e}+07$ \\
V3 & -0.067 & $-5.197^{*}$ & -1.601 & $-1.148 \mathrm{e}+07$ \\
\hline W1 & $0.081^{*}$ & $8.729^{* * *}$ & 3.682 & $9.884 \mathrm{e}+06$ \\
\hline W2 & 0.033 & $5.220^{* * *}$ & $3.909^{* * *}$ & $2.753 \mathrm{e}+06$ \\
\hline
\end{tabular}

Source: Author's work

The data in table 6 , shows that the 0.50 median of ROCE raises by 0.036 for every single unit rise in variable $\mathrm{Pl}$.

It is possible to find out data for the rest of the variables in the same way, so 0.50 median of ROE decreases by about 5.197 for every one unit increase in variable V2 or raises by 5.220 for every single unit rise in variable $\mathrm{W} 1$.

Figure 2 shows that the linear regression gives a good estimation of the ROCE, $\mathrm{ROE}, \mathrm{ROA}$ and EVA when variables P1, P2, P3, P4, V1, V2, V3, W1 and $\mathrm{W} 2$ is close to 0. But as variables $P 1, P 2, P 3, P 4, V 1, V 2, V 3, W 1$ and $W 2$ increase, the mean of the ROCE, ROE, ROA and EVA given P1, P2, P3, P4, V1, V2, V3, W1 and W2 become less meaningful.

Furthermore, the more uniform dispersion around a plotted line is, the more accurate estimation of 0.50 medians can be made for each increase of P1, P2, P3, $\mathrm{P} 4, \mathrm{~V} 1, \mathrm{~V} 2, \mathrm{~V} 3, \mathrm{~W} 1$ and $\mathrm{W} 2$ despite the increasing variability. 
Figure 2

Comparison between ROCE, ROA, ROE and EVA median regression models
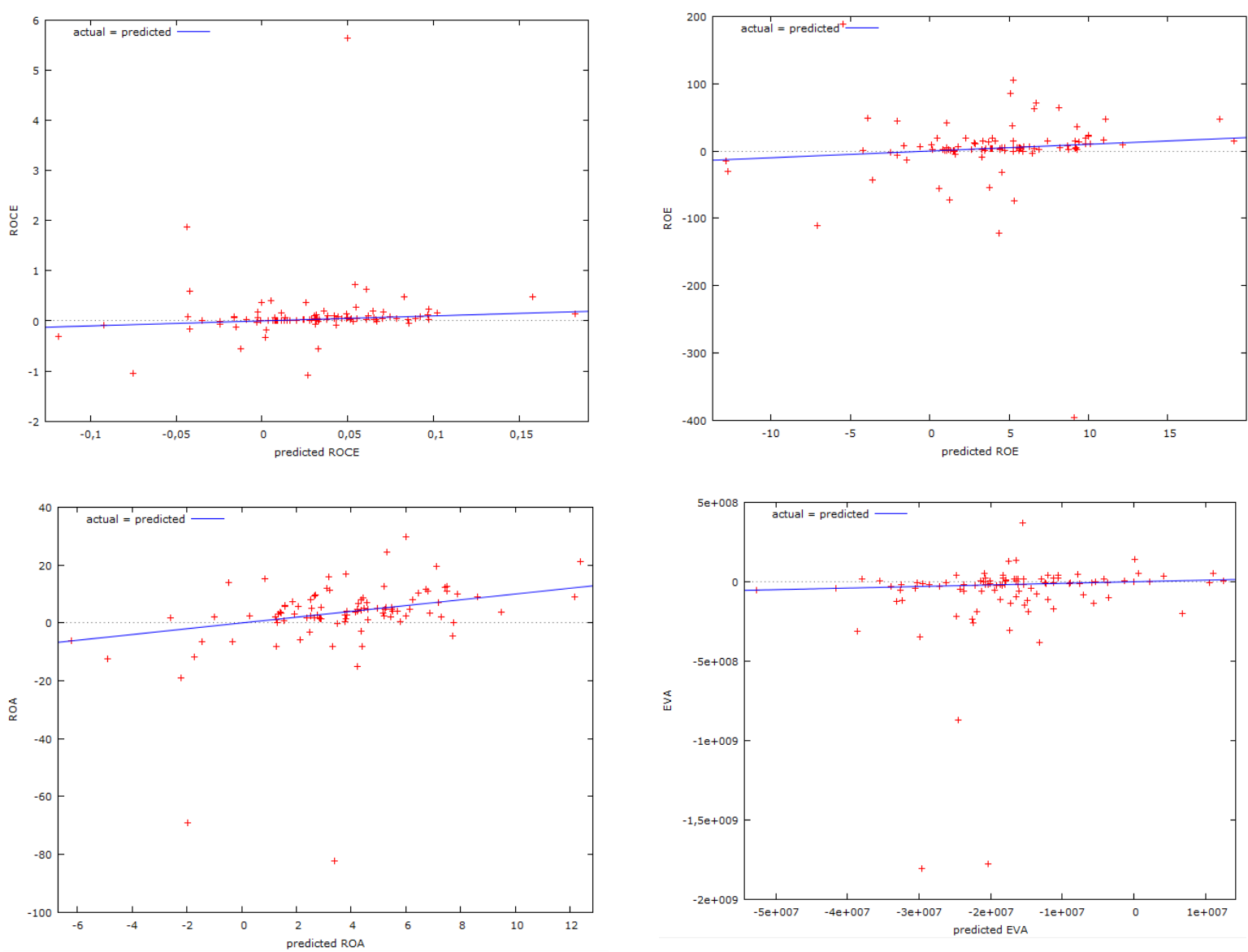

Source: Author's work

Table 7 shows regression coefficients sign and statistical significance in the following way: (a) if an independent variable significantly impact a dependent variable, the level of significance is stated, which can be from $1 \%, 5 \%$ or $10 \%$, and is marked with the prefix (+) or $(-)$, which determines the direction of the impact; (b) if there is no significance of the independent the marking $\varnothing$ is used.

Table 7

Regression coefficients sign and statistical significance

\begin{tabular}{lcccc}
\hline & ROCE & ROE & ROA & EVA \\
\hline & $\tau=0.5$ & $\tau=0.5$ & $\tau=0.5$ & $\tau=0.5$ \\
P1 & $\varnothing$ & $\varnothing$ & $\varnothing$ & $\varnothing$ \\
P2 & $\varnothing$ & $\varnothing$ & $\varnothing$ & $(+) 5 \%$ \\
P3 & $\varnothing$ & $\varnothing$ & $\varnothing$ & $\varnothing$ \\
P4 & $\varnothing$ & $\varnothing$ & $\varnothing$ & $\varnothing$ \\
V1 & $\varnothing$ & $\varnothing$ & $\varnothing$ & $\varnothing$ \\
V2 & $\varnothing$ & $(-) 10 \%$ & $\varnothing$ & $\varnothing$ \\
V3 & $(+) 10 \%$ & $(+) 1 \%$ & $\varnothing$ & $\varnothing$ \\
W1 & $\varnothing$ & $(+) 1 \%$ & $(+) 1 \%$ & $\varnothing$ \\
W2 & $\varnothing$ & $(-) 1 \%$ & $\varnothing$ & $\varnothing$ \\
\hline
\end{tabular}

Source: Author's work 
In our research a company's reputation is measured in three dimensions, where every dimension contains a certain number of variables, so the first dimension of corporate reputation: Products and services includes the variables P1 - Guarantee of products and services; P2 - Development of innovative services; P3 - Quality of products and services and P4- Level of products and services for a given price (Value for money). By using median regression analysis we have confirmed that out of the four variables of product and services reputation one of the variables has a significant impact on financial indicators in Croatian companies. However, P2 development of innovative services, as one of the four variables that describe a dimension of product and services reputation, is statistically significant in one of the financial indicator. The analysis confirms that P2 - development of innovative services has a significantly positive impact on EVA (5\%). It has been proven that innovation contributes to better company performance (Lumpkin and Dess, 1996 cited in Rosli and Sidek, 2013) as well as to the overall performance (see Rosli and Sidek, 2013). Also, Rosli and Sidek (2013) in their research state that product and process innovation significantly affect company performance especially product innovation which has a greater impact than process innovation. Furthermore, Lin (2011) claims that service innovation, directly and indirectly, affects company performance where the quality of service presents an important mediator, which also supports our research. It can be concluded that since one of the four variables of product and services reputation has a more significant impact, that our first hypothesis $\mathrm{Hl}$ : There is a significant impact of products and services as a dimension of corporate reputation on financial performance, is partially accepted.

The dimension of vision and leadership reputation which includes the variables $\vee 1$ - company management; $\mathrm{V} 2$ - vision for the future and $\mathrm{V} 3$ - quality of leadership, was also investigated. Our research confirms that $\mathrm{V} 2$ - vision for the future has a negative impact on ROE (significant at $10 \%$ ) as a dependent variable of financial performance, and variable V3 - quality of leadership has a positive impact on ROCE (significant at 10\%) and ROE (significant at 10\%), as a measure of financial business performance. The quality of leadership depends on how much the leadership has adopted the fundamental values of a company's business activity. The more ethical the values are the more quality leadership there is. The impact of such a quality of leadership can be seen in the positive economic results, like an increased productivity, efficiency or a higher share price (see Storr, 2004) which supports our findings. The negative impact of the variable $\mathrm{V} 2$ - vision for the future on ROE may be explained with the assumption that the examinees think that if the leadership is too focused on vision or that if the vision is unrealistic that this demands additional investment of capital to achieve that it, that it has a negative impact on ROE. As with the variable $\mathrm{V} 1$ - company management no significant impact has been registered, the second hypothesis $\mathrm{H} 2$ : There is a significant impact of vision and leadership as a dimension of corporate reputation on financial performance is partially accepted.

Our research confirms that the working conditions as a dimension of corporate reputation significantly affect financial performance. This may indicate that the working conditions could be an important factor of corporate reputation in Croatian companies. However, variable W1 - quality of a company as an employer, as one of the dimensions of working conditions has a significantly positive effect on ROE, ROA, as on the financial business performance. The working conditions are a result of the organizational culture and climate. Whereas the organizational culture affects the ethics in decision making, the organizational climate affects job satisfaction and company loyalty (Trevino, 1986). The more the culture and climate are based on 
ethical values, the better the working conditions are, the productivity of the company is better and in the end more successful (Orlitzky et al., 2003; Verschoor, 1998; Webley and More, 2003) which supports our research.

Furthermore, variable W2 - quality of employees has a negative significant impact on ROE which is opposite than the results of the other authors (Huselid, 1995; Becker and Huselid, 1998). Such a result can be justified by the assumption that the examinees thought that quality workers are also more expensive, have bigger salaries, so they cost more and have a negative impact on ROE. Consequently, the results of the research confirm our third hypothesis H3: There is a significant impact of working conditions as a dimension of corporate reputation on financial performance, and it is fully accepted.

\section{Conclusion}

This article gives a comprehensive overview of corporate reputation, the dimensions that determine it and their impact on financial performance of a company. The authors have researched the correlation between individual dimensions of reputation and the financial performance of a company. The research confirms that all three dimensions that make up corporate reputation: product and services reputation, vision and leadership reputation and working conditions reputation have a complete or partial impact on financial performance which proves their importance in the management of the total corporate reputation. The analysis confirms that the impact of the development of innovative services, quality of leadership and the quality of a company as an employer have a significantly positive effect on the financial performance of a company whereas the vision for the future and quality of employees have a negative impact. The contribution of this research is that we measured the impact of each individual dimension of corporate reputation on each separate financial measure.

A closer look at the data also suggested that quality of leadership, as a variable of vision and leadership reputation and quality of a company as an employer, as a variable of working condition reputation have the greatest impact on the financial performance measure. Both variables have an impact on two measures, quality of leadership on ROCE and ROE and quality of a company as an employer on ROE and ROA, and from this we can see that both variables have the greatest influence on the financial performance of a company, and based on the research that has been carried out we consider them the most important variables that make up an overall corporate reputation. Consequently, the role of the leaders is to create an organizational culture and climate that is based on ethical values and that with their behavior and activity serve as a good role model for the employees. The leaders need to support ethical working conditions that have a positive impact on moral, dedication and employee productivity (ISO, 2014) which makes the company as an employer a better quality one, and this is the only way for a company to realize a long-term successful, sustainable and social responsible business activity.

In the research certain limitations can be registered. First, the data was collected on the basis of the citizen's personal estimations and did not include other stakeholders. Interviewing managers, investors, subcontractors and other stakeholders would give a wider and more realistic picture of each company. Second, the research is geographically focused on the territory of Croatia which creates certain limitations. The economic, legal, cultural and social make up of a country certainly has an impact on a company's business activity. So, it would be justified to research the reputation of companies in countries with a similar or completely different make up and to compare the acquired results with the ones 
acquired in Croatia. Finally, the third limitation is connected to the choice of the instrument of measurement, which is a common problem when researching corporate reputation. If we add to that the fact that there is still no unified definition of reputation in a business context or a unified instrument for measurement with the same type and number of variables, the possibility of comparison of the results of research of corporate reputation of companies in different countries is still made difficult.

\section{References}

1. Allianz Risk Barometer (2015), „Top Business Risks 2015“, Allianz SE and Allianz, available at: http://www.agcs.allianz.com/assets/PDFs/Reports/Allianz-RiskBarometer-2015 EN.pdf (10 July 2017).

2. Allianz Risk Barometer (2016), „Top Business Risks 2015“, Allianz SE and Allianz, available

at: http://www.agcs.allianz.com/assets/PDFs/Reports/AllianzRiskBarometer2016.pdf (10 July 2017).

3. AON (2017), "Global Risk Management Survey 2017", available at: http://www.aon.com/2017-global-risk-management-survey/downloadreports.jsp (10 July 2017).

4. Banai, E., Mikulincer, M., Shaver, P. R. (2005), "Selfobject Needs in Kohut's Self Psychology: Links With Attachment, Self-Cohesion, Affect Regulation, and Adjustment", Psychoanalytic Psychology, Vol. 22, No. 2, pp. 224-260.

5. Barich, H., Kotler, P. (1991), „A framework for marketing image management", MIT Sloan Management Review, Vol. 32, No. 2, pp. 94-104.

6. Barnett, M. L., Jermier, J. M., Lafferty, B. A. (2006), „Corporate reputation: The definitional landscape", Corporate reputation review, Vol. 9, No. 1, pp. 26-38.

7. Baum, C. F. (2013), "Quantile regression, EC 823: Applied Econometrics", Boston College, available at: http://fmwww.bc.edu/ECC/S2013/823/EC823.S2013.nn04.slides.pdf (12 July 2017).

8. Becker, B. E., Huselid, M. A. (1998), „Human resources strategies, complementarities, and firm performance", available at: http://mgt2.buffalo.edu/files/faculty/ohr/becker/Publications/HumanResourcesS trategies.pdf (10 July 2017).

9. Bendixen, M., Abratt, R. (2007), "Corporate identity, ethics and reputation in supplier-buyer relationships", Journal of Business Ethics, Vol. 76, No. 1, pp. 69-82.

10. Bierens, H. J., Ginther, D. K. (2000), "Integrated Conditional Moment Testing of Median Regression Models", available at: https://www.researchgate.net/profile/Herman Bierens/publication/228391525 In tegrated Conditional Moment Testing of Median Regression Models/links/0046 3515b1fcb39775000000.pdf (12 July 2017).

11. Brown, B. (1998), „Do stock market investors reward companies with reputations for social performance?", Corporate Reputation Review, Vol. 1, No. 3, pp. 271280.

12. Cambridge dictionary (2017), „Reputation“, Cambridge dictionary online, available at: http://dictionary.cambridge.org/dictionary/english/reputation (05 July 2017).

13. Collins, J. C., Porras, J. I. (2002). Built to Last. Successful Habbits of Visionary Copanies, New York, HarperCollins Publishers.

14. De la Fuente Sabaté, J. M., De Quevedo Puente, E. (2003), „Empirical analysis of the relationship between corporate reputation and financial performance: $A$ survey of the literature", Corporate Reputation Review, Vol. 6, No. 2, pp. 161-177. 
15. Deloitte (2014), „2014 global survey on reputation risk Reputation@Risk“, Deloitte Touche Tohmatsu Limited, available at: www.deloitte.com/reputationrisksurvey (10 July 2017).

16. Fombrun, C. J. (2007), "List of lists: A compilation of international corporate reputation ratings", Corporate Reputation Review, Vol. 10, No. 2, pp. 144-153.

17. Fombrun, C. J., Gardberg, N. A., Sever, J. M. (2000), „The Reputation QuotientSM: A multi-stakeholder measure of corporate reputation", Journal of brand management, Vol. 7, No. 4, pp. 241-255.

18. Fombrun, C. J., Van Riel, C. B. (1997), "The reputational landscape“, Corporate reputation review, Vol. 1, No. 2, pp. 5-13.

19. Fombrun, C., Foss, C. (2004), "Business ethics: Corporate responses to scandal", Corporate Reputation Review, Vol. 7, No. 3, pp. 284-288.

20. Fombrun, C., Shanley, M. (1990), „What's in a name? Reputation building and corporate strategy", Academy of management Journal, Vol. 33, No. 2, pp. 233258.

21. Fortune (2017), "World's Most Admired Companies", available at: http://fortune.com/worlds-most-admired-companies/ (10 July 2017).

22. Gotsi, M., Wilson, A. M. (2001), "Corporate reputation: seeking a definition", Corporate Communications: An International Journal, Vol. 6, No. 1, pp. 24-30.

23. Gray, E. R., Balmer, J. M. (1998), "Managing corporate image and corporate reputation", Long range planning, Vol. 31, No. 5, pp. 695-702.

24. Grgić, D. (2008a), „Instrumenti mjerenja reputacije poduzeća“(„Measuring Instruments of Corporate Reputation"), Tržište, Vol. 20, No. 2, pp. 231-249.

25. Grgić, D. (2008b), „Teorijski okviri reputacije poduzeća” („The theoretical frame of the corporate reputation"), Ekonomski pregled, Vol. 59, No. 5-6, pp. 266-288.

26. Grgić, D. (2012), „Indeks reputacije poduzeća: Empirijsko istraživanje u bankovnom sektoru" ("Corporate Reputation Index: Empirical Research in Banking Sector"), Tržište, Vol. 24, No. 1, pp. 23-45.

27. Griffin, J. J., Mahon, J. F. (1997), "The corporate social performance and corporate financial performance debate: Twenty-five years of incomparable research", Business \& society, Vol. 36, No. 5, pp. 5-31.

28. Gruden, Z. (2003), "Pravi self - preduvjet stvaralaštva" ("The True Self Prerequisite to Creativity"), Nova prisutnost, Vol. 1-2, pp. 295-299.

29. Hall, R. (1992), "The strategic analysis of intangible resources", Strategic management journal, Vol. 13, No. 2, pp. 135-144.

30. Hall, R. (1993), "A framework linking intangible resources and capabiliites to sustainable competitive advantage", Strategic management journal, Vol. 14, No. 8, pp. 607-618.

31. Hammond, S. A., Slocum, J. W. (1996), "The impact of prior firm financial performance on subsequent corporate reputation", Journal of Business Ethics, Vol. 15, No. 2, pp. 159-165.

32. Helm, S. (2005), "Designing a formative measure for corporate reputation", Corporate reputation review, Vol. 8, No. 2, pp. 95-109.

33. Highhouse, S., Broadfoot, A., Yugo, J. E., Devendorf, S. A. (2009), "Examining corporate reputation judgments with generalizability theory", Journal of Applied Psychology, Vol. 94. No. 3, pp. 782-789.

34. Highhouse, S., Lievens, F., Sinar, E. F. (2003), "Measuring attraction to organizations", Educational and psychological Measurement, Vol. 63, No. 6, pp. 986-1001. 
35. Huselid, M. A. (1995), "The impact of human resource management practices on turnover, productivity, and corporate financial performance", Academy of management journal, Vol. 38, No. 3, pp. 635-672.

36. ISO (2014), "Discovering ISO 26000", International Organization for Standardization, Genève, available at: https://www.iso.org/files/live/sites/isoorg/files/archive/pdf/en/discovering iso 26 000.pdf (12 July 2017).

37. Klopotan (2016), "Utjecaj komunikacije društvene odgovornosti putem web stranica i društvenih mreža na reputaciju poduzeća" ("Impact of Corporate Responsibility Communication over the Company Web Site and Social Networks to Business Reputation"), doctoral thesis, Celje, Fakultete za komercialne in poslovne vede.

38. Lin, L. (2011), „The impact of service innovation on business performance: Evidence from firm-level data in Chinese tourism sector", in Service Systems and Service Management (ICSSSM), 8th International Conference on, IEEE, pp. 1-5.

39. Mason, J. C. (1993), "What image do you project?", Management Review, Vol. 82, No. 11, pp. 10-16.

40. Merriam-Webster dictionary (2017), "Reputation", Merriam-Webster Dictionary Online, available at: https://www.merriamwebster.com/dictionary/reputation (05 July 2017).

41. Orlitzky, M. (2005), "Social responsibility and financial performance: Trade-off or virtuous circle", University of Auckland Business Review, Vol. 7, No. 1, pp. 37-43.

42. Orlitzky, M., Schmidt, F. L., Rynes, S. L. (2003), "Corporate social and financial performance: A meta-analysis", Organization studies, Vol. 24, No. 3, pp. 403-441.

43. Oxford dictionary (2017), "Reputation", Oxford dictionary Online, available at: https://en.oxforddictionaries.com/definition/reputation (05 July 2017).

44. Ponzi, L. J., Fombrun, C. J., Gardberg, N. A. (2011), „RepTrak ${ }^{\mathrm{TM}}$ pulse: Conceptualizing and validating a short-form measure of corporate reputation", Corporate Reputation Review, Vol. 14, No. 1, pp. 15-35.

45. Roberts, P. W., Dowling, G. R. (2002), "Corporate reputation and sustained superior financial performance", Strategic management journal, Vol. 23, No. 12, pp. 1077-1093.

46. Roman, R. M., Hayibor, S., Agle, B. R. (1999), "The relationship between social and financial performance: Repainting a portrait", Business \& Society, Vol. 38, No. 1, pp. 109-125.

47. Rosli, M. M., Sidek, S. (2013), „The Impact of Innovation on the Performance of Small and Medium Manufacturing Enterprises: Evidence from Malaysia", Journal of Innovation Management in Small \& Medium Enterprises, Vol. 2013, pp. 1-16.

48. Schwaiger, M. (2004), "Components and parameters of corporate reputation-an empirical study", Schmalenbach Business Review, Vol. 56, pp. 46-71.

49. Sever Mališ, S. (2017), „Povezanost financijskih i nefinancijskih pokazatelja U funkciji ostvarivanja kvalitete poslovanja poduzeća“ („Relationship between financial and non-financial indicators in the function of achieving the quality of business operations"), in Žager, L. (ed.), "Analiza financijskih izvještaja", ("Financial reports analysis"), Zagreb, Masmedia.

50. Sobol, M. G., Farrelly, G. (1988), "Corporate reputation: A function of relative size or financial performance?", Review of Financial Economics, Vol. 24, No. 1, pp. 45-59.

51. Storr, L. (2004), "Leading with integrity: A qualitative research study", Journal of Health Organization and Management, Vol. 18, No. 6, pp. 415-434. 
52. Trevino, L. K. (1986), „Ethical decision making in organizations: A person-situation interactionist model", Academy of management Review, Vol. 11, No. 3, pp. 601617.

53. Treviño, L. K., Butterfield, K. D., McCabe, D. L. (1998), "The ethical context in organizations: Influences on employee attitudes and behaviors", Business Ethics Quarterly, Vol. 8, No. 3, pp. 447-476.

54. Treviño, L. K., Nelson, K. A. (2011). Managing Business Ethics: Straight Talk about How to Do it Right, Hoboken, John Wiley \& Sons.

55. Turban, D. B., Cable, D. M. (2003), "Firm reputation and applicant pool characteristics", Journal of Organizational Behavior, Vol. 24, No. 6, pp. 733-751.

56. Ugoji, K., Dando, N. Moir, L. (2007). Does Business Ethics Pay? - Revised, The value of ethics training", London, Institute of Business Ethics.

57. Verschoor, C. C. (1998), „A study of the link between a corporation's financial performance and its commitment to ethics", Journal of Business Ethics, Vol. 17, No. 13, pp. 1509-1516.

58. Vig, S., Dumičić, K. (2016), "Impact of commitment to business ethics to nonfinancial business performance", Interdisciplinary Description of Complex Systems, Vol. 14, No. 2, pp. 165-181.

59. Walsh, G., Beatty, S. E. (2007), "Customer-based corporate reputation of a service firm: scale development and validation", Journal of the academy of marketing science, Vol. 35, No. 1, pp. 127-143.

60. Webley, S., More, E. (2003). Does business ethics pay. Ethics and financial performance, London, Institute of Business Ethics.

\section{About the authors}

Silvija Vig is a Lecturer at the Polytechnic of Međimurje, Čakovec and at the Academy of Dramatic Art - Zagreb. Now she attends post-graduate doctoral study at the Faculty of Economics \& Business - Zagreb. Her main research fields include business ethics, ethical organisational culture and leadership. The author can be contacted at silvija.vig@mev.hr.

Ksenija Dumičić is a Full Professor Tenured at the Department of Statistics, Faculty of Economics \& Business, University of Zagreb. Her main research fields include sampling, statistics, statistics for business and economics, sampling for social and business surveys, statistical quality control. The author can be contacted at: kdumicic@efzg.hr.

Igor Klopotan is a Lecturer at University North, Varaždin. He completed postgraduate doctoral study at the Faculty for Commercial and Business Sciences in Celje, Slovenia. His main research fields include management, customer loyalty, employee loyalty, socially responsible business. The author can be contacted at: igor.klopotan@unin.hr. 